\title{
Enigmatic Microalgae from Aeroterrestrial and Extreme Habitats in Cosmetics: The Potential of the Untapped Natural Sources
}

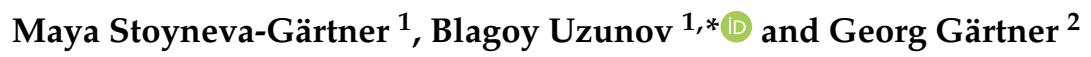 \\ 1 Department of Botany, Faculty of Biology, Sofia University “St. Kliment Ohridski”, 8 Dragan Tsankov Blvd., \\ BG-1164 Sofia, Bulgaria; mstoyneva@uni-sofia.bg \\ 2 Institut für Botanik der Universität Innsbruck, Sternwartestrasse 15, A-6020 Innsbruck, Austria; \\ georg.gaertner@uibk.ac.at \\ * Correspondence: buzunov@uni-sofia.bg
}

Received: 28 February 2020; Accepted: 13 April 2020; Published: 18 April 2020

\begin{abstract}
With the increasing demand for natural and safe products in cosmetics, algae with their diverse and valuable bioactive compounds are gaining vital importance. Until now, cosmetics have focused mainly on the use of freshwater and marine algae. However, algae are not restricted to aquatic habitats. They are found in essentially every type of aeroterrestrial and extreme environment on the Earth. There, they have to cope with harsh ecological conditions and have developed special strategies to thrive in these inimical habitats. Although not thoroughly studied, their adaptations include protective biochemical compounds which can find their application or are already used in the field of cosmetics. With proper cultivation techniques, algae from these habitats can provide novel sources of high-value functional products for the cosmetics industry, which have the advantage of being obtained in eco-friendly and cost-effective processes. However, it has to be considered that a few aeroterrestrial and extremophilic algae can be toxin producers, and in order to ensure conformity to the safe quality standards, all new ingredients must be properly tested. The aim of the present review is to unveil the hidden and underestimated potential of the enigmatic algae of aeroterrestrial and extreme habitats for the rapidly developing modern cosmetic industries.
\end{abstract}

Keywords: thermal algae; snow algae; soil algae; anti-aging; cosmeceutics skincare; haircare

\section{Introduction}

Nowadays, with the development of new social paradigms regarding youth and beauty, millions of consumers use cosmetic personal care products (PSP) routinely as part of their daily life [1]. At the same time, there is an increase in consumers' expectations, in which increased demands on one's own appearance have to take into consideration the growing environmental concerns of modern society. Therefore, ingredients which are not only cheap but match modern consumers' requests for "natural" and "healthier" products provide additional advantages for the cosmetic industry [1]. Novel and innovative cost-effective technologies became the way to satisfy the growing demands of the health-conscious consumer [2]. In 1962, Reed [3] introduced the term cosmeceutical with four statements supporting the idea to improve the quality of products used in cosmetics. Over the years, the term acquired a new meaning, first proposed by Kligman [4]. Currently, there is growing evidence for the consolidation of cosmetics and pharmaceuticals to encompass the biologically active compounds retaining therapeutic value, with increasing use of the term cosmeceuticals in this understanding [5-7]. In this rapidly developing branch of cosmetics, the role of natural compounds is emerging in response to the new challenges of the modern market with the basic premise that novel bioactive substances 
from natural sources are safer, with lower potential toxicity and are equally or even more efficacious than artificial substances [6]. Therefore, with the increasing demand for natural and safe products in both cosmetics and cosmeceuticals, algae, with their diverse and valuable bioactive compounds, are gaining vital importance [5,8-10]. Moreover, some of these compounds are extracted from fish or other aquatic organisms, or from higher plants in activities connected with important environmental concerns (e.g., overfishing, overexploiting of wild medicinal plants and other natural resources), which has prompted their more tolerable isolation from algae [11]. In this way, algae, which provide natural and safe products obtained by eco-friendly processes, became established as a sustainable source for new bio-based products $[8,12,13]$. The increase of studies in this field leads to the discovery of novel compounds and isolation of new species or strains by phycoprospecting, which recently is experiencing strong growth [14]. Currently, the global production of microalgae is focused on applications with high added value [1,15-19]. The variety of cosmetic formulations using bio-compounds or algal extracts is increasing [8]. The essential algal bioproducts which are finding an extensive range of applications for cosmetic and cosmeceutical purposes include different photosynthetic pigments (chlorophylls, phycobilines and carotenoids), lipids (including fatty acids and squalene), phenols, amino acids, peptides and proteins, carbohydrates (polysaccharides and phycocolloids), pterins and vitamins. These bio-based products are used as sunscreens, skin sensitizers and colorants and as agents for thickening, texturizing, tanning, moisturizing, whitening, water-binding, etc. for skin, hair and nails $[5,6,20,21]$.

The use of algae for beauty dates back centuries, when seaweeds were applied for fat reduction, skin improvement and anti-aging in procedures resembling modern thalassotherapy $[18,22,23]$. Therefore, it is no wonder that marine brown, red and green macroalgae are among the most researched and most used in cosmetics. At the same time, currently there is globally accumulating evidence for the broad use with different cosmetics and cosmeceutical applications of aquatic microalgae mainly from the genera Aphanizomenon, Arthrospira, Chlorella, Desmodesmus, Dunaliela, Haematococcus, Nannochloropsis, Scenedesmus, and Spirulina $[8,18,24,25]$. However, besides the classical freshwater, marine and hyperhaline habitats where these genera develop, there are other environments occupied by algae such as soils (including biotic crusts in hot and cold deserts), rock, bark and leaf surfaces, building facades, caves, ice, snow, permafrost, cryoconites, thermal springs, etc. [26-28]. The enigmatic world of these algae, rich in biodiversity and ecological adaptations, remains much more scarcely studied and practically unexplored. At the same time, algae from these habitats have to cope with much more severe, more rapidly and more drastically changing environmental conditions than their counterparts in the water. For example, with a lack of constant humidity and moisture, aeroterrestrial algae (which inhabit soils, rock, bark and other surfaces) have to withstand changing insolation, often accomplished by strong ultraviolet radiation (UVR), the broad range of daily and seasonally changing temperatures, desiccation, freezing, lack of constant nutrient supply or even biogenic poverty, etc. [26-28]. In contrast, aeroterrestrial cave algae develop in more constant humidity and temperature but have to live in almost complete darkness [26]. The algae of the most extreme environments-thermal springs and their contrasting cryophilic habitats like snow and ice-live at the edge of the biological limits and have to withstand very high (up to $98{ }^{\circ} \mathrm{C}$ ) or very low temperatures (down to $-30{ }^{\circ} \mathrm{C}$ ) combined with strong but changing insolation and poverty of nutrient supply [26-28]. Therefore, in the absence of general morphological differences with the aquatic species, the algae from these harsh habitats had to develop specific ultrastructural, physiological and biochemical features to be able to survive in the inimical environments [26-29]. Although not thoroughly studied, and therefore remaining enigmatic in many aspects, it is commonly accepted that these adaptations include series of protective natural compounds, which have great and promising potential for future applications in human life and cosmetics in particular. However, despite the great biodiversity of microalgae, few of them have been screened for chemical compositions, and only a handful have been exploited on an industrial scale $[2,30]$. Many biomolecules in algae have not yet been studied and are waiting for their use in cosmetics [5]. 
The complexity of algal chemical composition makes microalgae exploitable resources for valuable and novel products, the production of which is cost-effective [2]. Moreover, cultivation of aeroterrestrial or extremophilic algae under ambient environmental conditions reduces the dependency on seasons and the need to shut off operations during extreme climatic conditions [2]. The diversity of methods and techniques of cultivation of microalgae developed for biotechnological purposes (e.g., [31]) is out of the scope of the present review, the aim of which is to summarize the knowledge on the application of aeroterrestrial (soil, aerophytic, cave algae) and extremophilic (thermal and cryophilic) algae and their valuable compounds in the field of cosmetics. This is accomplished by pointing out some interesting, but still unexplored, species and their compounds, with the idea to outline perspectives for their future inventions. In this way, we propose an improved insight important from an ecological perspective, which can serve as a guide to unveil the wide-range potential for cosmetic industries of microalgae on which the research community has not strongly focused and which have not yet achieved public awareness and thus remain quite underestimated.

\section{Algae in Skincare with Special Attention to Sunscreen and Anti-Aging Compounds}

Algae from aeroterrestrial and extremophilic habitats are commonly exposed to oxidative stress and develop efficient protective systems against reactive oxygen species (ROS) and free radicals to protect the damage of biologically important macromolecules. In humans, the production of ROS, caused by the oxidative stress from the excessive skin exposure to UVR (consisting of two basic types-UV-A and UV-B rays), also can result in DNA damage despite the fact that skin cells have various protective mechanisms and strategies (such as antioxidants, DNA repair enzymes and stress signaling) [10]. Oxidative DNA damage and oxidative stress are known to result in wide range of pathological disorders and are associated with aging processes [32]. Skin aging in particular is a complex process caused by various stressors (besides the intrinsic, or endogenous factors) and induces many changes such as thinning, dryness, laxity, fragility, enlarged pores, hyperpigmentation, fine lines and wrinkles [33,34]. Additionally, due to the growing awareness about skin cancer enhanced by sun exposure [35] sun-protecting cosmetics represents an area of high demand [36]. Therefore, in the past decades, the importance of protection measures against skin damage increased with interest focused on the use of UV filters, incorporated in a wide range of personal care products including sunscreens, facial make-up and lip care products [10,37]. The most important aspect in the development of these new UV filters became safety for both humans and natural environment. This means that a sunscreen must be heat- and photo-stable, non-irritant, non-sensitizing and non-phototoxic, and also should not have adverse effects when introduced into aquatic habitats [10]. In this way, algal pure bioactive compounds or extracts, which can play the role of natural filter, thus improving and enhancing the skin barrier against the harmful effects of UVR, rapidly became essential in cosmetics $[8,30,36,38]$.

Among natural products used in ingredients for skin protection, carotenoids, which are well-known as strong antioxidants and scavenging agents, have several applications as anti-aging and sunscreen compounds $[6,33,39]$. More than a single contribution could be attributed to these important compounds, which, besides the solar protection, are used in cosmetics as stabilizers and preservatives [6,40]. In algae, the carotenoids are quite diverse, and some of them are unique for certain species or taxonomic groups and are the group of photosynthetic second in importance and quantity after the most abundant chlorophylls [27]. Both carotenoids and chlorophyll increased when species from the soil cyanoprokaryotic genus Nostoc were cultivated in presence of UVR (for details, see [8]). This result once more confirms the important UV-protective role of photosynthetic pigments in algae.

Carotenoids such as astaxanthin, $\beta$-carotene, and lutein can be included as part of topical cosmetic products for protection against UV-induced damage $[18,20,24]$. Specifically, $\beta$-carotene is used in the formulation of skin care products [21,41]. The antioxidant properties of $\beta$-carotene helping against skin aging were found during studies with green and red algae $[5,42]$. In addition to this rejuvenating function and strong pro-vitamin A activity [38], $\beta$-carotene showed promising abilities in decreasing the risk of skin cancer among users $[5,43]$. In this respect, we would like to recall 
that $\beta$-carotene is one of the most spread photosynthetic pigments in algae [27]. Moreover, its high concentrations have been proven in different aeroterrestrial species and specifically in the members of the small algal class Eustigmatophyceae (mainly Vischeria), in which they could account for $60-85 \%$ of the total carotenoid content and over $5 \%$ of the dry weight (for details see [39]).

However, the potential of natural carotenoids is not completely explored: from more than 600 carotenoids reported in nature, very few are applied commercially, including in the field of cosmetics [38]. Besides $\beta$-carotene, valuable diverse carotenoids of cosmeceutical interest were found in the class Eustigmatophyceae, and in its aeroterrestrial unicellular genera Eustigmatos, Monodus and Vischeria in particular [39]. This study proved lutein as a novel pigment for the eustigmatophycean algae and presence of high amounts of astaxanthin. Both pigments are well known for their broad applications and are specifically important for skincare cosmetical products.

Lutein has an important role in skin health owing to its blue-light absorption and scavenging of free radicals that develop from the exposure to sunlight $[21,44,45]$. Besides the above-mentioned aeroterrestrial eustigmatophyceans, high lutein content $\left(3.55 \mathrm{mg} \mathrm{g}^{-1}\right)$ was proven in the green aeroterrestrial alga Muriellopsis sp. [2,46-48] and in the extremophilic $(\mathrm{pH}<2.5)$ green alga Coccomyxa acidophila when grown in urea [49]. Lutein was found in considerable amounts

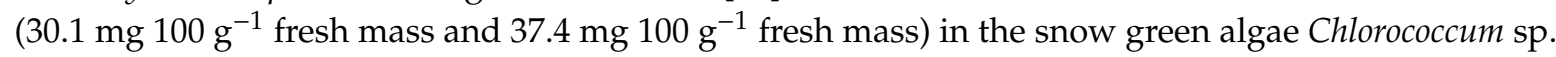
and Raphidonema nivale, respectively [50]. In these algae, lutein equaled or even exceeded the concentration of this valuable pigment in various fruits and vegetables used for human consumption.

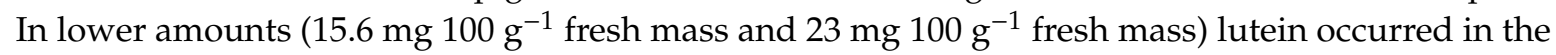
snow algae Chlamydomonas nivalis and Chlamydocapsa sp. [50]. A diverse carotenoid content was found in algae collected from "greenish" and "reddish" snow, with lutein as an abundant pigment in both of them [51]. The lutein extracted from other sources is usually 95\% esterified, whereas in microalgae, it is found in the free nonesterified form [2].

The numerous benefits of the secondary ketocarotenoid astaxanthin, which provides a multifunctional response to stress [52], include endurance and protecting the skin from premature aging, inflammation and UV-damage [38]. The red and orange color caused by the accumulation of astaxanthin appears as a protective shield in different cryophilic and aeroterrestrial green algae such as Bracteacoccus engadinensis, Chlainomonas spp., Chlamydomonas nivalis, Chlorococcum sp., Chloromonas polyptera, Chloromonas hindakii, Sanguina nivaloides, Sanguina aurantia, Tetracystis sp. and Trentepohlia spp. [53-62]. In contrast, other typical green snow algae of the genus Raphidonema (Trebouxiophyceae, Chlorophyta) are unable to develop such orange- or red-colored cell types [50,53]. However, laboratory experiments demonstrated that two species of the genus (Raphidonema nivale and $R$. sempervirens) exhibited an unusually high pool of primary xanthophyll cycle pigments, possibly serving as a buffering reservoir against excessive irradiation [50]. Besides the strong insolation and UVR, the snow algae are exposed to low temperatures (optimum about $12{ }^{\circ} \mathrm{C}$ ) and low nutrient supply, drastic temperature and light changes and possible desiccation [27,51]. A recent study on snow Chlorella sp. revealed that it also possesses a capacity for recovery after inhibition of photosynthesis by UVR [63]. Therefore, many products on the market (serums, powders, cremes, hydrating waters, moisturizers, body balms, etc.) use the survival strategy and compounds of these algae (in particular astaxanthin) for extending the cell longevity (e.g., [64]).

According to Stutz et al. [65] extracts of the green snow alga, Chlamydocapsa sp., can be used in skin protection and anti-aging products because of their similar action mainly in oxidative reactions related with damages from UVR and air pollution. The same extract, applied topically, can decrease transepidermal water loss and thus can help to avoid the formation of wrinkles after exposure to UVR, cold or dryness. Therefore, it was proposed as essential rejuvenating compound of the relevant hydrogel, anti-aging creme and cell-protecting serum, as well as in soaps and lotions [66,67].

Another carotenoid, lycopene, was considered as a potent natural antioxidant with possible application as a sunscreen and sunburn-preventing agent $[18,68]$. Today, lycopene is used in personal 
care formulations as an anti-aging agent [18]. The cyanoprokaryote Anabaena vaginicola had a substantially higher content of lycopene than all previously reported natural sources [69].

Antioxidant properties are known also for the natural carotenoid fucoxanthin, which was well-studied and explored from marine brown macroalgae from the class Phaeophyceae (for details, see [1], in which it is responsible for the brown color of the thalli [27]. Fucoxanthin is an important carotenoid in many other ochrophyte algae and specifically in the widespread diatoms, many of which are aeroterrestrial or inhabit extremophilic environments [26-28]. However, their potential application in the field of cosmetics needs investigation.

Tocopherols (vitamin E), which have antioxidant effects similar to carotenoids [5,43], are commercially isolated from vegetative oils or can be synthetized. Tocopherols from aquatic microalgae are more rarely investigated [38,70-73] when compared with marine macroalgae ([74,75] among many others). Even less is known about tocopherol production and accumulation in aeroterrestrial and extremophile algae. A search among 130 microalgal strains from four different taxonomic groups showed that $\alpha$-tocopherol was most abundant, whereas $\beta$ - and $\gamma$-tocopherol only appeared, if at all, in much smaller amounts [70]. However, a strong variability among strains was observed, and often closely related taxa could contain vastly different amounts of $\alpha$-tocopherol [70]. Among the tested algae, 37 were aeroterrestrial and some of them contained high amounts (up to $1062.02 \mu \mathrm{g} \mathrm{g}^{-1} \mathrm{dm}$ ) of $\alpha$-tocopherol: the green Bracteacoccus sp., Coccomyxa sp., Muriella terrestris, Stichococcus bacillaris, yellow-green Botrydiopsis intercedens, Heterococcus sp., Xanthonema sp., eustigmatophycean Monodus guttula, etc. Currently, the most bioactive form of vitamin E-the naturally occurring $R R R$ - $\alpha$-tocopherol-was discovered in Stichococcus bacillaris [76]. Considering the worldwide distribution of this aeroterrestrial filamentous alga [53], we note it as important potential renewable natural source of vitamin E. Two cryophilic species of green algae-Chlamydocapsa sp. and Raphidonema sempervirens-proved to be good $\alpha$-tocopherol producers [50]. They were suggested as interesting novel candidates for biotechnological applications [50] and for cosmetics, in particular, because tocopherol and tocopherol esters are often used in the formulation of lipstick, eye shadow, blushers, face powders and foundations, moisturizers, skin care products, bath soaps and detergents and many other products [77]. Algal tocopherols can be applied also in some common widely used products such as baby cleansing wipes and milk, eyelash enhancer serum, eyebrows growth serum, mustache wax, beard balm, beard oil, beard conditioner, and beard shampoo.

Phenols (also known as phenolics) are the largest group of plant secondary metabolites and play a role in protection mechanisms against oxidative stress or UV cytotoxic effects [1,78]. Marine algae, with their relatively high phenolics concentrations, were long in the focus of the researchers, and phlorotannins of brown algae could be outlined as the most studied group of phenolic compounds from algae [79]. However, less is known about phenols and their role in non-aquatic and extremophilic microalgae. The experiments of Duval et al. [62] demonstrated significant increase of the total phenolic content in the snow alga Chlamydomonas nivalis after five to seven days exposure to UVR. The possible use of phenolics as UV-screening compound, based on studies of soil cyanoprokaryotes Nostoc muscorum and Phormidium foveolarum, was noted in the summary by Singh et al. [80].

Scytonemin, a dimer of indolic and phenolic subunits, exists in two forms: yellow-brown oxidized hydrophobic form-fuscochlorin-only slightly soluble in organic solvents, and a more soluble in organic solvents reduced red form-fuscorhodin [80-83]. Scytonemin is considered as a unique natural product of special interest for formulation of sunscreen products due to its multiple roles as UV sunscreen and as an antioxidant with strong radical-scavenging activity [18,84]. For human use, it was already patented in the USA (for details see [6]). This photoprotective and photostable pigment in its hydrophobic yellow-brown form was isolated from the extracellular mucilage sheaths of some aeroterrestrial (including cryophilic), cave and thermal cyanoprokaryotes of the genera Scytonema, Stigonema, Nostoc, Calothrix, Lyngbya, Rivularia, Chlorogloeopsis and Hyella [18,35,80,84-92]. Additional interest for cosmetics comes from the fact that scytonemin was proven as a protein serine/threonine kinase inhibitor with anti-inflammatory activities, which can inhibit proliferation of 
human fibroblasts and endothelial cells $[31,85,93]$. Recently, from the organic extracts of Scytonema sp., dimethoxyscytonemin, tetramethoxyscytonemin and scytonin pigments have been isolated [94-96].

Another photoprotective pigment-the red lipid-soluble pigment gloeocapsin-is known from the mucilaginous sheaths of the cyanoprokaryote Gloeocapsa [97]. Although known for more than a century, it is still not characterized either chemically, ecologically or physiologically [97].

Mycosporine-like amino acids (MAAs), the strongest natural paramount molecules in sun protection due to their function as a primary sunscreen to reduce short-wavelength light, were considered to be novel antioxidants scavenging toxic oxygen radicals [98-101]. Therefore, currently all members of the MAAs family are recognized as potential fully safe and highly efficient health and beauty ingredients in sun care products as a promising alternative to the commercially available filters for skin protection from UVR [14,102-104]. Moreover, MAAs represent an important intracellular nitrogen reservoir [14,98], which have shown strong abilities in wound healing [14,104], and specifically, mycosporine-glycine has great antioxidant, anti-inflammatory and anti-aging activities, which makes it an important candidate for use in cosmeceutical fields [25,105].

MAAs from algae have been explored for commercial purposes, which has resulted, for instance, in commercial skin-care products for UV protection [6,73]. However, according to our knowledge, the sources were marine red algae $[6,73,106]$. MAAs can be accumulated also in algae from other ecological and taxonomical groups. The widely spread soil cyanoprokaryote Nostoc commune was among the first algae in which UV-absorbing MAAs were found [107]. They were classified among the unusual MAAs, covalently linked to oligosaccharides through the imine substituents [107]. The same MAAs were found in the microbial mats on Arctic ice shields [108,109]. Later, three glycosylated MAAs (hexose-bound porphyra-334 derivative and two-hexose bound palythine-threonine derivative) with multifunctional role of sunscreens and antioxidants were isolated from N. commune [110-112]. The glycosylated MAAs of N. commune are special for being excreted extracellularly, in contrast to other MAAs, which are concentrated within the cytoplasm [113]. Four MAAs (palythine, asterina, porphyra and palythene) were produced in the strain Nostoc sp. R76DM exposed to UVR [114]. Apart from their antioxidant and ROS-scavenging properties, these four MAAs were found to be exceedingly resistant also to temperature and $\mathrm{pH}$ and were outlined for possible use as active ingredients in cosmeceuticals [114]. Two other cyanoprokaryotes, Nostoc punctiforme ATCC 29133 and Anabaena variabilis ATCC 29413 were proven as producers of the MAA shinorin $[115,116]$. Shinorin, together with porpyra-334 and mycosporine-glycine, was found in Anabaena doliolum and Scytonema javanicum, where they also had multiple roles of shields against UVR and ROS scavengers but also helped to thrive in high temperatures $[80,97,117,118]$. Specific MAAS were found in cyanoprokaryotes from desert soil crusts $[10,119]$, and the presence of MAAs was determined in Arctic and Antarctic cyanoprokaryotic mats [120,121]. MAAs were also found in 13 genera of green aeroterrestrial algae from the class Trebouxiophyceae (phylum Chlorophyta): Apatococcus, Bracteacoccus, Chlorella, Coccomyxa, Elliptochloris, Myrmecia, Pabia, Prasiola, Prasiolopsis, Pseudochlorella, Pseudococcomyxa, Stichococcus and Trichophyllus and in three aeroterrestrial genera from the green class Klebsormidiophyceae (phylum Streptophyta): Klebsormidium, Hormidiella and Interfilum [14,61,122-128]. However, the MAAs in Klebsormidiophyceae were not the same as other known MAAs like palythine, asterina-330, mycosporine-glycine, shinorin and porphyra-334 [14,128]. More recently, a novel MAA, $\mathrm{N}-(5,6$ hydroxy-5(hydroxymethyl)-2-methoxy-3-oxo-1-cycohexen-1-yl) glutamic acid, named prasiolin, was isolated from another trebouxiophycean aeroterrestrial species-Prasiola calophylla [129]. This alga is spread abundantly in surface soil communities of temperate Europe [130] and could serve as potential commercial source of this novel MAA. Moreover, Hartmann et al. 2016 [129] suppose that other trebouxiophycean algae can synthetize the same or similar MAAs. It has to be stressed that production of MAAs was induced by exposure of algae to UVR in strains of Chlorella, Klebsormidium, Myrmecia incisa and Stichococcus in which these compounds were not detectable before exposure $[61,123,125]$.

MAAs were found as produced in significant amounts by snow algae Chlamydomonas nivalis and Scotiella nivalis $[73,122]$ and in the Antarctic samples from "reddish" and "greenish" snow [51]. 
The estimation of the biotechnological potential of MAAs on the background of the improvements and development of industrial-scale cultivation technologies shows that these natural metabolites have the potential to supplement or replace commercially available sunscreens $[10,131,132]$.

Due to high demands for safe and quality sunscreens in cosmetic industries, an area of special practical interest for cosmetics became the combination of MAAs with scytonemin after it was shown that Nostoc flagelliforme, a terrestrial cyanoprokaryote from arid environments exposed to intense solar radiation, showed complementary absorption of UV-B by MAAs and UV-A by scytonemin, thereby providing protection over the whole UVR range [133]. Other combinations, that of MAAs and specific biological compounds pterins, which also absorb UVR, were discovered in the aeroterrestrial filamentous cyanoprokaryotes of genera Microcoleus and Lyngbya [123,134,135].

The cold-adapted and freeze-resistant algae of the cryophyton, which have their optimum at low temperatures and inhabit ice, snow, permafrost or other cold environments and polar regions of the world, are producers of antifreeze proteins (AFPs), also designated as ice-structuring proteins (ISPs) $[73,136]$. AFPs are polypeptides that protect organisms living in extremely cold climates with very low temperatures because they are uniquely able to bind to ice crystals and thus to inhibit the recrystallization of small, extracellular ice crystals into larger, more damaging ones [136]. In this way, AFPs protect other proteins from damage and represent key elements for the survival of some organisms in subzero environments. Besides algae, different AFPs were found in plants, bacteria, fungi vertebrates and invertebrates (for details, see [136]). However, among algae, there are some cold-adapted strains of green unicellular microalgae which produce AFPs that additionally exhibit antifungal properties [for details, see [73]). AFPs are currently being explored in some formulations to reduce cold-induced damage in cosmetic products [73]. The extraordinary properties of AFPs allow hypothesizing a growing number of businesses including AFPs in their future formulation of products [73].

Bioactive peptides (BP) are specific protein fragments of physiological importance for most living organisms [137]. Most of the peptides used as ingredients in cosmeceutical preparations are obtained by chemical synthesis or by partial digestion of animal proteins, which makes them not fully accepted by consumers [137]. In contrast, the BPs derived from plants and microalgae possess a broad spectrum of biological activities and are considered to be more effective and safer than those produced through conventional methods. Once derived from plants or microalgae, BP can be used as combinations and mixture with other metabolites in cosmetic formulas and can exert their biological effects with very low risk of inducing allergenic reaction or undesired side effects [137]. Thus, their uses as ingredients in cosmetic products are acquiring more and more opportunities [137]. Doubtless, the phycoprospecting which can help to reveal new sources of unexplored BP with novel chemical features and unexpected biological properties can enhance more innovative opportunities to develop new products for the cosmetic market [137].

Of special interest in the cosmetic sector targeting sensitive and reactive skin types are glucans [18]. These polysaccharides with strong antioxidative properties belong to the active ingredients extracted from microalgae. Species rich in $\beta$-glucans were found in the aeroterrestrial red Porphyridium and in the cyanoprokaryote Nostoc flagelliforme $[18,138]$, and it is possible to suppose that further studies will reveal more such algae.

The polymer sporopollenin, broadly known as an inert component in higher plant pollen grains, exists as a resistant compound in the cell walls of some (mainly green) algae $[27,139,140]$. Owing to its ability to absorb most dangerous UV-B rays [6], it was believed to play role in UV protection and was mentioned among the sources for UV-screening compounds from aeroterrestrial algae Characium terrestre and Scotiellopsis rubescens [35,141]. Xiong et al. [142] even suggested that sporopollenin provides a constant protection, while MAAs are induced by radiation stress and occur with some delay. There is accumulated strong evidence that sporopollenin is safe and non-toxic $[6,139]$. Despite its chemical intactness, it can bind heavy metals [143], and its patented use as chelating agent suggests more possibilities for its use in cosmetic industries [6]. The presence of phenolics on sporopollenin endows it 
with antioxidant activity and suggests more applications and uses in the years to come of this unique renewable polymer that is plentiful in nature from a wide variety of plant sources [139].

Microalgae are responsible for the production of a range of lipids, but most commercially significant is their ability to synthesize polyunsaturated fatty acids (PUFAs). PUFAs play an important role in photoprotection, maintaining membrane fluidity and preventing intracellular ice crystal formation in organisms against extreme environmental conditions like high light intensity, UVR, and low temperature $[51,144,145]$. PUFAs in general aid in the prevention and treatment of scaly dermatitis and skin dehydration [146]. In this respect, the unicellular red species Porphyridium cruentum is regarded as another excellent future source of PUFA and related products [36,147], the carbohydrates of which have antioxidant and anti-inflammatory effects [148]. Microalgae are rich in essential PUFAs like $\omega-3$, and $\omega-6$ in particular, which are very important for the integrity and regeneration of tissues. Linoleic and linolenic acids are essential: $\gamma$-linolenic acid has some cosmetic applications like revitalizing the skin and slowing aging, while linoleic acid is also used for the treatment of hyperplasia of the skin [21,149].

Interesting composition of betaine lipids, with a possible role in adaptation to low $\mathrm{pH}$ and high temperatures, was found in the unicellular polyextremophilic red alga Galdieria sulphuraria, which inhabits acid thermal springs [150]. Diatoms from the thermal mud are able to produce sulpholipids analogous to those found in cyanoprokaryotes and endowed with anti-inflammatory and anti-viral properties [151].

In skin care products, lipid-based cosmetics, like cremes or lotions, enriched by algal extracts, are gaining commercial importance due to their both nourishing and protecting effects on the skin [36]. Algal extracts are gaining more importance in cosmetics due to their multiple and complex effects. For example, algal extracts from some red microalgae can be used for skin care, sun protection, refreshing or regenerating care products and anti-aging creams and as an anti-irritant in peelers $[30,146,152,153]$. The latter authors noted the abilities of secondary metabolites of certain marine microalgae to prevent blemishes, repair damaged skin, treat seborrhea, inhibit some inflammation processes and accelerate healing process [146]. It is possible to suppose with high probability that aeroterrestrial and extremophilic algae can provide similar or novel compounds with the same activities. In this respect, we have to note that extracts of the common aeroterrestrial eustigmatophycean Monodus subterraneus and green Chlorococcum minutum in combination with marine diatoms from the genera Thalassiosira and Chaetoceros showed properties in modulating the metabolism of human skin [154]. Extract from the widely distributed soil species Nostoc commune demonstrated high anti-oxidative activity [90]. Therefore, with possible addition of other compounds (oils, surfactants, waxes, etc.), they can be used in anti-aging products to intensify and stimulate collagen production [154].

When discussing the role of algae in the specific skin care products for photoprotective and anti-aging treatment, we have to stress that most of the mentioned compounds or extracts with antioxidative features proved to be effective also against rough texture, wrinkles and skin flaccidity $[8,20,155-159]$. Specifically, the algal extracts from hot saline waters induced markers (involucrin, filaggrin and trans glutaminase-1) for skin-barrier formation in keratinocytes, induced collagen expression in dermal fibroblasts and inhibited UVA-induced up-regulation of photo-aging markers (matrix metalloproteinase MMP-1 and cytokine IL-6)-[160]. A water extract from the aeroterrestrial cyanoprokaryote Chlorogloeopsis with UV-protective properties for keratinous tissue became of interest for sun creams and lotions, shampoo and lipsticks because it could prevent photo-aging, wrinkles formation and skin sagging $[8,161]$.

Since 2011, in skin care formulas, the anti-aging active ingredient with the tradename Alguronic acid was introduced to the market. Since then it was processed and formulated in a range of products. It has to be noted that the name is used for a mix of algae extracts and not a technical name referring to a single polysaccharide [162]. 


\section{Algae and Their Compounds as Humectants and Moisturizers}

Moisturization and hydration are essential for skin care in maintaining its healthy appearance and elasticity $[1,163]$. In addition to its good outlook, well-hydrated skin is better protected against harmful environmental factors [1,163]. In this respect, the adaptations of aeroterrestrial algae to limit water loss and to withstand desiccation are of ultimate interest. It is widely accepted that surviving dehydration was the main challenge that green algae had to face in order to colonize land. The capacity to retain cellular water then became very important, and algae developed special characteristics such as thickness of the cell walls and presence of mucilaginous layers formed by colloidal polysaccharides [164-167]. These macromolecules have a high capacity for water storage and can be linked to keratin through hydrogen bonds, thus improving skin moisturization $[1,163,168]$. Therefore, polysaccharides are of exceptional importance for cosmetic formulations as humectants and moisturizers. Until now, polysaccharides of marine and freshwater macroalgae and of some microalgae like eustigmatophycean Nannochloropsis [169] have been better studied and exploited, but the polysaccharides of other microalgae, with few exceptions, are still untapped. Among these exceptions with proven biotechnological applications are the extracellular mucilage coatings of cyanoprokaryotes, which are composed mainly of polyanionic polysaccharides formed by neutral sugars, uronic acids and proteins (for details, see [170]). In different species, more than 15 monosacharides were identified-rhamnose, fucose, xylose, mannose, glucose, galactose and glucuronic and galacturonic acids. These polysaccharids have additional value because they are endowed with anti-inflammatory properties. The inflammatory effect of the exopolysaccharids of the thermophilic alga Mastigocladus laminosus was proven and it was supposed that topical anti-inflammatory properties seem to be quite common for the sheaths of other cyanoprokaryotes (Phormidium, Nostoc) (for details see [170]). Until now, the dried biomass of M. laminosus was powdered, mixed with clay and applied on human skin to relieve rheumatoid arthritis and traumatic rheumatism (for details, see [170]), and we believe that besides therapeutic treatments it can find application for cosmetic purposes.

Chitin, the second most important natural polysaccharide polymer in the world after cellulose $[171,172]$ has a potential application in cosmetics related with moisturizing and its use as hydrating agent in cremes, soaps and lotions [6]. Chitin has anti-aging and skincare properties [7], and together with its main derivative, chitosan, chitin showed accelerating effects on the wound healing process [173]. The commercial interest in chitin and chitosan, and their derivatives, is increasing because of their beneficial properties such as biocompatibility, biodegradability, safety and also antimicrobial, antiviral, antifungal and antioxidant activities [172,174]. It is important to recall that it was long believed that chitin had limited presence in insects, crustaceans and fungi, and yet marine crustaceans are the main commercial source of chitin [170]. However, chitin was discovered as a cell-wall component in some algae, including aeroterrestrial and thermophilic species $[15,27,28,53]$.

Some algal amino acids and proteins also possess natural moisturizing abilities, which is exploited for keeping the skin hydrated and preventing drying of the skin cells [5,175]. For enrichment of beauty products mainly well-studied Spirulina and Chlorella have been applied, but we strongly believe that pigments and metabolites from extremophilic and aeroterrestrial algae can find their place in the modern cosmetic industry. For instance, Nostoc commune moisturizing serum has significant moisturizing, anti-inflammatory, whitening and nourishing effects for skin while being non-irritating to skin [169]. This serum provides significant comfort and softness without greasiness [169]. In addition, it is believed that resistance to desiccation could be enhanced by presence of sugar alcohols $[166,176]$ and sporopollenins $[123,141,177]$, which were reported in some terrestrial green algae [61].

The pro-vitamin A carotenoids $\beta$-carotene and $\beta$-cryptoxanthin, but also the non-pro-vitamin A carotenoids lutein, zeaxanthin and astaxanthin, were able to induce the synthesis of hyaluronan (hyaluronic acid) which is involved in skin hydration [18,178]. Topical administration of lutein and zeaxanthin provided significant effects in terms of skin elasticity and hydration and induced reductions 
in skin lipid peroxidation $[178,179]$. All these carotenoids were found in aeroterrestrial strains of the eustigmatophycean genus Vischeria [39].

The triterpene squalene is an antioxidant and an important biosynthetic precursor to all human steroids [180]. In cosmetics, it is better applied in its saturated form obtained after hydrogenation, named squalane. Both squalene and squalane receive additional value when used to stimulate ideal skin properties because they are not irritants to human skin and are non-toxic at the concentrations used in cosmetics [11]. Besides its use as an antioxidant, squalene can be applied as an antistatic and an emollient in moisturizing creams, penetrating the skin rapidly without leaving fatty traces or sensations and mixing well with other oils and vitamins [11]. Recently, the extraction of squalene in an eco-friendly way from microalgae was promoted (U.S. Patent 10087467B2 [11]). These microalgae belong to the stramenopilic group of thraustochytrids (alternatively classified as fungi or algae) which inhabit marine and freshwaters, but also mud and decaying mangrove leaves [181,182]. Besides squalene, thraustochytrids produce other valuable lipids such as PUFAs, and docosahexaenoic acid (DHA) in particular $[183,184]$. The commercial interest in thraustochytrids is based on their ability to accumulate lipids faster than any other oleaginous microorganisms [185]. Currently, there is enough fermentation capacity projected for these organisms to support the replacement of at least $15 \%$ of the global fish oil production $[181,186]$. Consequently, thraustochytrids have the biotechnological potential to yield a lasting positive environmental impact in the fisheries and aquaculture sector [181].

\section{Algae and Their Compounds in Skin Whitening}

For preventing hyper skin pigmentation, cosmetics looks for natural compounds that can inhibit, control or prevent melanogenesis and, consequently, skin pigmentation and therefore can be used for cosmetic formulations for depigmentation $[1,187]$. Tyrosinase is the key enzyme of melanin synthesis, and in this respect, the demand for natural products capable of inhibiting the tyrosinase enzyme and stimulating bleaching is growing all over the world $[1,8,188,189]$. The carotenoid zeaxanthin is considered an antityrosinase substance, and pure extract of the marine eustigmatophycean microalga Nannochloropsis oculata, which contains zeaxanthin, has been patented to be used in creams [189]. This pigment occurrs in different aeroterrestrial eustigmatophyceans and specifically in Eustigmatos and Vischeria [39]. Research activities demonstrated that other carotenoids not only absorb UVR but have similar abilities to zeaxanthin to inhibit actions on melanin synthesis $[8,190]$. Among them, astaxanthin also presents interesting depigmentation properties which provide a protection for skin from age spots by reducing melanin production by $40 \%$ and improving all skin layers [191-193]. Therefore, astaxanthin, can be included as part of topical cosmetic products for protection against hyper-pigmentation, and the same is valid for $\beta$-carotene and lutein $[18,20,24,193]$. Fucoxanthin can also help to reduce the activity of tyrosinase and melanogenesis $[193,194]$. In addition, fucoxanthin has the ability to counteract oxidative stresses caused by UVR, due to which it is currently used in cosmeceuticals $[193,195,196]$. Although these authors investigated fucoxanthin from marine brown macroalgae (kelp) we have to stress that this pigment is widely spread in different classes of the phylum Ochrophyta, including ecological groups which are in the focus of this paper. The potential of these algae in this respect is completely unexplored.

\section{Algae and Their Compounds in Tanning}

Although comprising just a handful, some carotenoids and algae can have application in skin tanning and suntan products. Cantaxanthin from the marine eustigmatophycean genus Nannochloropsis was outlined for its use in tanning products $[18,197]$. The presence of canthaxanthin was proven also in the aeroterrestrial eustigmatophycean genera Eustigmatos, Monodus and Vischeria (for details see [39]). Canthaxanthin was found also in the red phase samples of the snow algae Chlamydomonas nivalis, Chlamydocapsa sp. and Chlorococcum sp., with the highest amounts in Chlamydocapsa sp. [50]. $\beta$-carotene is used in the formulation of suntan products [21,41]. Joshi et al. [5] summarized data on the ubiquitous Chlorella vulgaris indicating the role of its vitamins in skin toning and healing of dark circles. 


\section{Algae and Their Compounds as Colorants}

Colorants for cosmetic formulations such as eye shadow, face makeup and lipstick are currently obtained from red microalgae $[8,146]$. One of the most important among these red microalgae is the genus Porphyridium, which predominantly develops in moist terrestrial habitats [53]. These red unicellular algae are used to obtain the natural water-soluble pigments phycoerythrins and phycocyanins, which are considered alternatives to synthetic colorings due to their marginal toxicity $[6,18,198]$. These protein-containing pigments are also antioxidants and are used in lipsticks and eyeliners $[18,138]$, while the phycocyanin extracted from Porphyridium purpureum has been applied in eyeshadows $[18,152,199]$. Its special use in decorative cosmetics is explainable by the fact that pigment does not change with $\mathrm{pH}$ (4 to 5) and the color remained constant under light $[18,200]$. For presence of stable phycocyanin, the red thermo-acidophilic Galdieria has been utilized in biotechnology [201]. High thermostability of phycocyanin was highlighted for the thermophilic cyanoprokaryote Synechoccoccus lividus and was related with its shifted absorption spectrum (absorption maximum 608 instead of 620) [110]. Thermophilic cyanoprokaryotes with lower temperature optima such as Oscillatoria terrebriformis contain phycoerithryn [110]. Porphyridium purpureum (under its synonymic name Porphyridium cruentum [202]) is the most commonly used species for phycoerythrin production that can be added in hair colours due to their long-lasting properties $[169,203]$.

\section{Algae and Their Compounds in Thickening or Water-Binding}

Some bioactive algal compounds in the cosmetic industry are applied for thickening or water-binding [8,20,155-159]. Among such active ingredients extracted from microalgae are polysaccharides which, just as those from macroalgae, are used as gelling agents and thickeners in different cosmetic formulas, as well as for moisturizing $[18,204]$. Similarly, polysaccharides from various green microalgae species can be included in cosmetic products for the purposes of antioxidant activity, gelling or thickening $[18,24]$.

The most promising microalga for commercial purposes is the unicellular red alga Porphyridium purpureum (Syn. P. cruentum), which produces a sulphated galactan exopolysaccharide that can replace carrageenans in many applications [38]. Sulfated polysaccharide from Porphyridium appears to be an excellent candidate to substitute hyaluronic acid as a biolubricant and exhibits antioxidant activity against the auto-oxidation of linoleic acid and thereby preventing skin aging [205]. Carotenoids and chlorophylls with antioxidant properties may help in protection against oil oxidative process in emulsions containing large amounts of oily phase $[8,38]$.

\section{Algae and Their Compounds in Hair Care}

Vitamins of the green unicellular Chlorella vulgaris were noted as encouraging hair growth by treating dandruff [5]. The precursor of vitamin $A-\beta$-carotene-is used in the formulation of hair conditioners and shampoos [21,41]. Tocopherol and tocopherol esters are often used in hair conditioners [77].

Carbohydrates are considered active raw materials that play an important role in cosmetics products for hair conditioning, hair waving or straightening. Natural carbohydrates are characterized by antibacterial, antioxidative, anti-inflammatory, antitumor and antiviral properties [21,206,207]. Chitin and chitosan, which can be used in blends with other natural or synthetic polymers [171], have possible applications as humectants and moisturizing agents in hair care products [6,7]. Currently, in these applications, chitosan is more used because of its ability to interact with keratin, forming transparent, elastic films over hair fibers [7,171]. Chitosan and its derivatives have been included in a large variety of hair products such as shampoos, rinses, permanent wave agents, hair colorants, styling lotions, hair sprays and hair tonics to avoid hair damage, to reduce static electricity and to increase the suppleness of the hair, hair softness and hair strength $[7,171,208,209]$. The effect was even more pronounced when chitosan was blended with hyaluronic acid and collagen: the resulting covering of 
hair led to an increase in hair thickness and to an improvement in hair's mechanical properties with an enhancement in the general appearance and conditioning of the hair [209]. Chitosan gelling ability in hydroalcoholic mixtures was used to formulate chitosan in gel form $[173,208]$. However, not used in hair cosmetics are the properties of chitosan to remove sebum and oils from hairs (due to hydrophobic character), its antibacterial and antifungal activity, as well as its role as thickening polymer and its role in surfactant stability for stabilizing emulsions [171].

Some microalgal extracts are constituents of various hair care products [30,35]. Apart from the application in skincare products, the extracts of Monodus subterraneus, Chlorococcum minutum, Thalassiosira spp. and Chaetoceros spp. were proposed for use in formulations for reduction of hair loss because of their stimulation effect on hair follicles [154]. Extracts of red microalgae can also be found in hair care [8].

\section{Aftershaves, Deodorants, Makeup and Other Personal Care Products}

$\beta$-carotene is used in the formulation of cosmetics and personal care products such as aftershave lotions and makeup [21,41]. Other pigments from microalgae such as chlorophyll can easily be extracted [210] and used in cosmetics, for example, in deodorants, due to their ability to mask odors, as well as in toothpastes and hygiene products [18].

Carbohydrates play an important role in cosmetics products such as deodorant [21,206,207], and specifically chitosan is also applied in oral care (toothpaste, chewing gum) [171]. In addition, a unique compound of monoterpenes group- $\beta$-phellandrene-has great commercial potential including personal care, cleaning products and pharmaceutics [211].

\section{Safety Concerns}

Most of the compounds included in the review are safe and non-toxic, but we have to recall that some microalgae are capable of producing toxic metabolites (algal toxins). Toxins produced by cyanoprokaryotes and other microalgae (dinoflagellates, haptophytes, diatoms, euglenophytes) are of great safety concern due to their serious impact on human health [212,213]. Therefore, in order to answer the safety concerns, all products must be subjected to chemical analysis once they are developed as new active ingredients for cosmetic applications. However, some toxic metabolites can be exploited for their allelochemical nature, and it is known that apart from the toxin, some microalgae are also enriched with several pharmacologically active compounds that have antibacterial, anticancerous, antifungal, antiplasmodial, antiviral and immunosuppressive activities [80]. At the same time, we have to boldly underline that at the present state of knowledge, it is widely accepted that the number of potential toxin producers from subaerial and extremophilic habitats is much lower in comparison with their counterparts from aquatic habitats. This provides an additional advantage to the microalgae from these groups for future research and applications in cosmetics.

\section{Conclusions}

The results from this study demonstrate the clear and almost unrevealed potential in the microalgae adapted to the harsh ecological conditions of subaerial and extreme environments. These enigmatic organisms, which developed adaptations and surveillance strategies over billions of years, have a large potential as innovative natural sources of a vast variety of bioactive compounds. Moreover, these microalgae are a source of added-value functional compounds, with scientific evidence showing their benefits for human health and well-being, which can meet the increasing consumer demands for natural and healthier cosmetics. These compounds can be obtained through cost-effective and eco-friendly cultivation processes in order to avoid raising environmental concerns about over-exploiting of the wild natural resources. The subaerial and extremophilic microalgae are of interest for cosmetics industry mainly because of the presence of antioxidants and other active compounds preventing hair and skin premature aging, dehydration, hyperpigmentation, etc. caused by UVR or air pollution, and their low toxicity effects. Moreover, more than a single contribution 
could be attributed to each algal species or bioactive compound, as reported in the provided review. However, we have to recall that, though only a handful, some algae are potential toxin producers, and in order to ensure conformity to the safe quality standards, all new ingredients must be properly tested. In this respect, bioprospecting approaches can help to unveil the best novel, valuable and safe microalgal candidates for application in the rapidly developing consumer-friendly cosmetic industries.

Author Contributions: Conceptualization, M.S.-G.; writing—original draft preparation, M.S.-G.; writing-review and editing, B.U. and G.G.; project administration, B.U.; funding acquisition, B.U. All authors have read and agreed to the published version of the manuscript.

Funding: This research was funded by SCIENTIFIC RESEARCH FUND OF THE BULGARIAN MINISTRY OF EDUCATION, grant number KP-06-OPR06/2-18.12.2018.

Conflicts of Interest: The authors declare no conflict of interest.

\section{References}

1. Pimentel, F.B.; Alves, R.C.; Rodrigues, F.; Oliveira, M.B.P.P. Macroalgae-derived ingredients for cosmetic industry-An update. Cosmetics 2018, 5, 2. [CrossRef]

2. Bux, F. (Ed.) Biotechnological Applications of Microalgae Biodiesel and Value-Added Products; CRC Press, Taylor \& Francis Group: Boca Raton, FL, USA, 2013.

3. Reed, E. The definition of "cosmeceuticals". J. Soc. Cosm. Chem. 1962, 13, 103-106.

4. Kligman, A.M. Why cosmeceuticals? Cosmet. Toilet. 1993, 108, 37-38.

5. Joshi, S.; Kumari, R.; Upasani, V.N. Applications of algae in cosmetics: An overview. Int. J. Innov. Res. Sci. Eng. Technol. 2018, 7, 1269-1278.

6. Jahan, A.; Ahmad, I.Z.; Fatima, N.; Ansari, V.A.; Akhtar, J. Algal bioactive compounds in the cosmeceutical industry: A review. Phycologia 2017, 56, 410-422. [CrossRef]

7. Aranaz, I.; Acosta, N.; Civera, C.; Elorza, B.; Mingo, J.; Castro, C.; Gandía, M.D.L.; Caballero, A.H. Cosmetics and cosmeceutical applications of chitin, chitosan and their derivatives. Polymers 2018, 10, 213. [CrossRef]

8. Ariede, M.B.; Candido, T.M.; Jacome, A.L.M.; Velasco, M.V.R.; de Carvalho, J.C.M.; Baby, A.R. Cosmetic attributes of algae-A review. Algal Res. 2017, 25, 483-487. [CrossRef]

9. Santhosh, S.; Dhandapani, R.; Hemalatha, N. Bioactive compounds from microalgae and its different applications-A review. Adv. App. Sci. Res. 2016, 7, 153-158.

10. Derikvand, P.; Llewellyn, C.A.; Purton, S. Cyanobacterial metabolites as a source of sunscreens and moisturizers: A comparison with current synthetic compounds. Eur. J. Phyc. 2017, 52, 43-56. [CrossRef]

11. Pora, B.; Qian, Y.; Caulier, B.; Comini, S.; Looten, P.; Segueilha, L. Method for the Preparation and Extraction of Squalene from Microalgae. U.S. Patent 10087467B2, 2 October 2018.

12. Michalak, I.; Chojnacka, K. Algal extracts: Technology and advances. Eng. Life Sci. 2014, 14, 581-591. [CrossRef]

13. Yun, E.J.; Choi, I.G.; Kim, K.H. Red macroalgae as a sustainable resource for biobased products. Trends Biotechnol. 2015, 33, 247-249. [CrossRef] [PubMed]

14. Stoyneva-Gärtner, M.; Uzunov, B.; Gärtner, G.; Radkova, M.; Atanassov, I.; Atanassova, R.; Borisova, C.; Draganova, P.; Stoykova, P. Review on the biotechnological and nanotechnological potential of the streptophyte genus Klebsormidium with pilot data on its phycoprospecting and polyphasic identification in Bulgaria. Biotechnol. Biotechnol. Equip. 2019, 33, 559-578. [CrossRef]

15. Gärtner, G.; Uzunov, B.; Ingolic, E.; Kofler, W.; Gacheva, G.; Pilarski, P.; Zagorchev, L.; Odjakova, M.; Stoyneva, M. Microscopic investigations (LM, TEM and SEM) and identification of Chlorella isolate R-06/2 from extreme habitat in Bulgaria with a strong biological activity and resistance to environmental stress factors. Biotechnol. Biotechnol. Equip. 2015, 29, 536-540. [CrossRef]

16. Stolz, P.; Obermayer, B. Manufacturing microalgae for skin care. Cosmet. Toilet. 2005, 120, 99-106.

17. Milledge, J.J. Commercial application of microalgae other than as biofuels: A brief review. Rev. Environ. Sci. Biotechnol. 2011, 10, 31-41. [CrossRef]

18. Mourelle, M.; Gómez, C.; Legido, J. The potential use of marine microalgae and cyanobacteria in cosmetics and thalassotherapy. Cosmetics 2017, 4, 46. [CrossRef] 
19. Radkova, M.; Stoyneva-Gärtner, M.; Dincheva, I.; Stoykova, P.; Uzunov, B.; Dimitrova, P.; Borisova, C.; Gärtner, G. Chlorella vulgaris H 1993 and Desmodesmus communis H 522 for low-cost production of high value microalgal products. Biotechnol. Biotechnol. Equip. 2019, 33, 243-249. [CrossRef]

20. Wang, H.M.D.; Chen, C.C.; Huynh, P.; Chang, J.S. Exploring the potential of using algae in cosmetics. Bioresour. Technol. 2015, 184, 355-362. [CrossRef]

21. Basily, H.S.; Nassar, M.M.; Diwani, G.I.; Abo El-Enin, S.A. Exploration of using the algal bioactive compounds for cosmeceuticals and pharmaceutical applications. Egyp. Pharmaceut. J. 2018, 17, 109-120.

22. Lembi, C.A.; Waaland, J.R. Algae and Human Affairs; Cambridge University Press: New York, NY, USA, 1989.

23. Charlier, R.H.; Chaineux, M.-C.P. The healing sea: A sustainable coastal ocean resource: Thalassotherapy. J. Coast. Res. 2009, 25, 838-856. [CrossRef]

24. Dixon, C.; Wilken, L.R. Green microalgae biomolecule separations and recovery. Bioresour. Bioprocess. 2018, 5, 14. [CrossRef]

25. Hamidi, M.; Kozani, P.S.; Kozani, P.S.; Pierre, G.; Michaud, P.; Delattre, C. Marine bacteria versus microalgae: Who is the best for biotechnological production of bioactive compounds with antioxidant properties and other biological applications? Mar. Drugs 2020, 18, 28. [CrossRef] [PubMed]

26. Round, F.E. The Ecology of Algae; Cambridge University Press: Cambridge, UK, 1981.

27. Graham, L.E.; Graham, J.M.; Wilcox, L.W. Algae, 2nd ed.; Pearson Benjamin Cummings: San Francisco, CA, USA, 2009.

28. Stoyneva-Gärtner, M.; Uzunov, B. Bases of Systematics of Algae and Fungi; House Dzhey Ey Em Dzhi Books: Sofia, Bulgaria, 2017.

29. Seckbach, J.; Chapman, D.J.; Garbary, D.J.; Oren, A.; Reisser, W. Algae and cyanobacteria under environmental extremes: Final comments. In Algae and Cyanobacteria in Extreme Environments; Seckbach, J., Ed.; Springer: Berlin/Heidelberg, Germany, 2007; pp. 781-786. [CrossRef]

30. Spolaore, P.; Joannis-Cassan, C.; Duran, E.; Isambert, A. Commercial applications of microalgae. J. Biosci. Bioeng. 2006, 101, 87-96. [CrossRef]

31. Coêlho, D.F.; Tundisi, L.L.; Cerqueira, K.S.; Rodrigues, J.R.S.; Mazzola, P.G.; Tambourgi, E.B.; Souza, R.R. Microalgae: Cultivation aspects and bioactive compounds. Braz. Arch. Biol. Technol. 2019, 62, e19180343. [CrossRef]

32. Chu, W.-L. Potential applications of antioxidant compounds derived from algae. Curr. Top. Nutraceut. R. 2011, 9, 83-98.

33. Alparslan, L.; Sekeroglu, N.; Kijjoa, A. The potential of marine resources in cosmetics. Curr. Pers. MAPs. 2018, 2, 53-66. [CrossRef]

34. Berthon, J.Y.; Nachat-Kappes, R.; Cadoret, J.-P.; Bey, M.; Filaire, E. Commentary on “Marine algae as attractive source to skin care". J. Skin 2018, 2,3.

35. Sharma, N.; Sharma, P. Industrial and biotechnological applications of algae: A review. J. Adv. Plant. Biol. 2017, 1, 1-25. [CrossRef]

36. Pulz, O.; Scheibenbogen, K.; Groß, W. Biotechnology with Cyanobacteria and microalgae. In Biotechnology: Special Processes, 2nd ed.; Rem, H.-J., Ed.; Wiley-VCH Verlag GmbH: Weinheim, Germany, 2001; Volume 10, pp. 105-136.

37. Stiefel, C.; Schwack, W. Rapid screening method to study the reactivity of UV filter substances towards skin proteins by high-performance thin-layer chromatography. Int. J. Cosmet. Sci. 2013, 35, 588-599. [CrossRef]

38. Gouveia, L.; Batista, A.P.; Sousa, I.; Raymundo, A.; Bandarra, N.M. Microalgae in novel food products. In Food Chemistry Research Developments; Papadopoulos, K.N., Ed.; Nova Science Publishers, Inc.: New York, NY, USA, 2008; pp. 75-111.

39. Stoyneva-Gärtner, M.; Stoykova, P.; Uzunov, B.; Dincheva, I.; Atanassov, I.; Draganova, P.; Borisova, C.; Gärtner, G. Carotenoids in five aeroterrestrial strains from Vischeria/Eustigmatos group: Updating the pigment patterns of Eustigmatophyceae. Biotechnol. Biotechnol. Equip. 2019, 33, 250-267. [CrossRef]

40. Xhauflaire-Uhoda, E.; Fontaine, K.; Piérard, G.E. Kinetics of moisturizing and firming effects of cosmetic formulations. Int. J. Cosmet. Sci. 2008, 30, 131-138. [CrossRef] [PubMed]

41. Leon, R.; Martin, M.; Vigara, J.; Vilchez, C.; Vega, J.M. Microalgae mediated photoproduction of b-carotene in aqueous organic two-phase systems. Biomol. Eng. 2003, 20, 177-182. [CrossRef] 
42. Blume-Peytavi, U.; Kottner, J.; Sterry, W.; Hodin, M.W.; Griffiths, T.W.; Watson, R.E.B.; Hay, R.J.; Griffiths, C.E.M. Age-Associated skin conditions and diseases: Current perspectives and future options. Gerontologist 2016, 56, 230-242. [CrossRef] [PubMed]

43. Keen, M.A.; Hassan, I. Vitamin E in dermatology. Indian Dermatol. Online J. 2016, 7, 311-314. [CrossRef]

44. Hahn, T.; Lang, S.; Ulber, R.; Muffler, K. Novel procedures for the extraction of fucoidan from brown algae. Process. Biochem. 2012, 47, 1691-1698. [CrossRef]

45. Yaakob, Z.; Ali, E.; Zaina, A.; Mohamad, M.; Takriff, M.S. An overview: Biomolecules from microalgae for animal feed and aquaculture. J. Biol. Res. 2014, 21, 6. [CrossRef]

46. Del Campo, J.A.; García-González, M.; Guerrero, M.G. Outdoor cultivation of microalgae for carotenoid production: Current state and perspectives. Appl. Microbiol. Biotechnol. 2007, 74, 1163-1174. [CrossRef]

47. Del Campo, J.A.; Rodríguez, H.; Moreno, J.; Varga, M.Á.; Rivas, J.; Guerrero, M.G. Lutein production by Muriellopsis sp. in an outdoor tubular photobiorector. J. Biotechnol. 2001, 81, 289-295. [CrossRef]

48. Del Campo, J.A.; Rodríguez, H.; Moreno, J.; Varga, M.Á.; Rivas, J.; Guerrero, M.G. Carotenoid content of chlorophycean microalgae: Factors determining lutein accumulation in Muriellopsis sp. (Chlorophyta). J. Biotechnol. 2000, 76, 51-59. [CrossRef]

49. Casal, C.; Cuaresma, M.; Vega, J.M.; Vilchez, C. Enhanced productivity of a lutein-enriched novel acidophile microalga grown on urea. Mar. Drugs 2011, 9, 29-42. [CrossRef]

50. Leya, T.; Rahn, A.; Lütz, C.; Remias, D. Response of arctic snow and permafrost algae to high light and nitrogen stress by changes in pigment composition and applied aspects for biotechnology. FEMS Microbiol. Ecol. 2009, 67, 432-443. [CrossRef] [PubMed]

51. Kim, B.K.; Joo, H.; Lee, B.; Lee, D.-H.; Ahn, I.-Y.; Ha, S.-Y. Physiological characteristics and related biochemical parameters of snow algae from King George Island, Antarctica. Ocean Sci. J. 2018, 53, 621-630. [CrossRef]

52. Lemoine, Y.; Schoefs, B. Secondary ketocarotenoid astaxanthin biosynthesis in algae: A multifunctional response to stress. Photosynth. Res. 2010, 106, 155-177. [CrossRef] [PubMed]

53. Ettl, H.; Gärtner, G. Syllabus der Boden-, Luft- und Flechtenalgen, 2nd ed.; Springer: Berlin/Heidelberg, Germany, 2014.

54. Remias, D.; Lütz, C. Characterisation of esterified secondary carotenoids and of their isomers in green algae: A HPLC approach. Algol. Stud. 2005, 124, 85-94. [CrossRef]

55. Remias, D.; Lütz-Meindl, U.; Lütz, C. Photosynthesis, pigments and ultrastructure of the alpine snow alga Chlamydomonas nivalis. Eur. J. Phycol. 2005, 40, 259-268. [CrossRef]

56. Remias, D.; Albert, A.; Lütz, C. Effects of realistically simulated, elevated UV irradiation on photosynthesis and pigment composition of the alpine snow alga Chlamydomonas nivalis and the arctic soil alga Tetracystis sp. (Chlorophyceae). Photosynthetica 2010, 48, 269-277. [CrossRef]

57. Remias, D.; Wastian, H.; Lütz, C.; Leya, T. Insight into the biology and phylogeny of Chloromonas polyptera (Chlorophyta), an alga causing orange snow in Maritime Antarctica. Antarct. Sci. 2013, 25, 648-656. [CrossRef]

58. Remias, D.; Pichrtová, M.; Pangratz, M.; Lütz, C.; Holzinger, A. Ecophysiology, secondary pigments and ultrastructure of Chlainomonas sp. (Chlorophyta) from the European Alps compared with Chlamydomonas nivalis forming red snow. FEMS Micorbiol. Ecol. 2016, 92, fiw030. [CrossRef]

59. Procházková, L.; Remias, D.; Řezanka, T.; Nedbalová, L. Ecophysiology of Chloromonas hindakii sp. nov. (Chlorophyceae), causing orange snow blooms at different light conditions. Microorganisms 2019, 7, 434. [CrossRef]

60. Procházková, L.; Leya, T.; Křižková, H.; Nedbalová, L. Sanguina nivaloides and Sanguina aurantia gen. et spp. nov. (Chlorophyta): The taxonomy, phylogeny, biogeography and ecology of two newly recognised algae causing red and orange snow. FEMS Microbiol. Ecol. 2019, 95, fiz064. [CrossRef]

61. Rindi, F. Terrestrial green algae: Systematics biogeography and expected responses to climate change. In Climate Change, Ecology and Systematics; (Systematics Association Special Volume Series, pp. I-Iv); Hodkinson, T., Jones, M., Waldren, S., Parnell, J., Eds.; Cambridge University Press: Cambridge, UK, 2011; pp. 201-228. [CrossRef]

62. Duval, B.; Shetty, K.; Thomas, W.H. Phenolic compounds and antioxidant properties in the snow alga Chamydomonas nivalis after expose to light. J. Appl. Phycol. 1999, 11, 559. [CrossRef]

63. Rivas, C.; Navarro, N.; Huovinen, P.; Gómez, I. Photosynthetic UV stress tolerance of the Antarctic snow alga Chlorella sp. modified by enhanced temperature? Rev. Chil. Hist. Nat. 2016, 89, 7. [CrossRef] 
64. Red Snow Algae Powder for Skin Cell Longevity. Available online: https://www.cosmeticsandtoiletries. com/formulating/category/antiaging/Red-Snow-Algae-Powder-for-Skin-Cell-Longevity-277607461.html (accessed on 25 February 2020).

65. Stutz, C.S.; Schmid, D.; Zülli, F. Use of an Extract from Snow Algae in Cosmetic or Dermatological Formulations. U.S. Patent 20100316720A1, 16 December 2010.

66. Stutz, C.S.; Schmid, D.; Zülli, F. Use of an Extract from Snow Algae in Cosmetic or Dermatological Formulations. U.S. Patent 8206721B2, 26 June 2012.

67. Snow Algae and Novel Peptides Revive Aging Skin. Available online: https://www.lifeextension.com/ magazine/2015/4/snow-algae-and-novel-peptides-revive-aging-skin (accessed on 25 February 2020).

68. Singh, P.; Rani, B.; Chauhan, A.K.; Maheshwari, R. Lycopene's antioxidant activity in cosmetics meadow. Int. Res. J. Pharm. 2013, 3, 46-47.

69. Hashtroudi, M.S.; Shariatmadari, Z.; Riahi, H.; Ghassempour, A. Analysis of Anabaena vaginicola and Nostoc calcicola from Northern Iran, as rich sources of major carotenoids. Food Chem. 2013, 136, 1148-1153. [CrossRef]

70. Mudimu, O.; Koopmann, I.K.; Rybalka, N.; Friedl, T.; Schulz, R.; Bilger, W. Screening of microalgae and cyanobacteria strains for $\alpha$-tocopherol content at different growth phases and the influence of nitrate reduction on $\alpha$-tocopherol production. J. Appl. Phycol. 2017, 29, 2867. [CrossRef]

71. Goiris, K.; Colen, W.V.; Wilches, I.; León-Tamariz, F.; Cooman, L.D.; Muylaert, K. Impact of nutrient stress on antioxidant production in three species of microalgae. Algal Res. 2015, 7, 51-57. [CrossRef]

72. Mokrosnop, V.M.; Zolotareva, E.K. Microalgae as tocopherol producers. Biotechnol. Acta 2014, 7, $26-33$. [CrossRef]

73. Martínez-Francés, E.; Escudero-Oñate, C. Cyanobacteria and microalgae in the production of valuable bioactive compounds. Microalgal Biotechnol. 2018, 6. [CrossRef]

74. de Sousa, M.B.; dos Santos Pires, K.M.; de Alengar, D.B.; Sampaio, A.H.; Saker-Sampaio, S. $\alpha$ - and $\beta$-carotene, and $\alpha$-tocopherol in fresh seaweeds. Ciênc. Tecnol. Aliment. 2008, 28, 953-958. [CrossRef]

75. Panayotova, V.; Merzdhanova, A.; Dobreva, D.A.; Zlatanov, M.; Makedonski, L. Lipids of Black Sea algae: Unveiling their potential for pharmaceutical and cosmetic applications. J. IMAB 2017, 23, 1747-1751. [CrossRef]

76. Sivakumar, G.; Jeong, K.; Lay, J.O. Biomass and RRR- $\alpha$-tocopherol production in Stichococcus bacillaris strain siva2011 in a balloon bioreactor. Microb. Cell Fact. 2014, 13, 79. [CrossRef] [PubMed]

77. Tocopherol. Available online: https://cosmeticsinfo.org/ingredient/tocopherol (accessed on 25 February 2020).

78. Holmann, P.C.H. Evidence for health benefits of plant phenols: Local or systemic effects? J. Sci. Food Agric. 2001, 81, 842-852. [CrossRef]

79. Freile-Pelegrín, Y.; Robledo, D. Bioactive phenolic compounds from algae. In Bioactive Compounds from Marine Foods: Plant and Animal Sources, 1st ed.; Hernández-Ledesma, B., Herrero, M., Eds.; John Wiley \& Sons, Ltd.: Chichester, UK, 2014; pp. 113-129. [CrossRef]

80. Singh, R.; Parihar, P.; Singh, M.; Bajguz, A.; Kumar, J.; Singh, S.; Singh, V.P.; Prasad, S.M. Uncovering potential applications of Cyanobacteria and algal metabolites in biology, agriculture and medicine: Current status and future prospects. Front. Microbiol. 2017, 8, 515. [CrossRef] [PubMed]

81. Garcia-Pichel, F.; Castenholz, R.W. Characterization and biological implications of scytonemin, a cyanobacterial sheath pigment1. J. Phycol. 1991, 27, 395-409. [CrossRef]

82. Proteau, P.J.; Gerwick, W.H.; Garcia-Pichel, F.; Castenholz, R. The structure of scytonemin, an ultraviolet sunscreen pigment from the sheaths of cyanobacteria. Experientia 1993, 49, 825-829. [CrossRef] [PubMed]

83. Scytonemin. Available online: https://en.wikipedia.org/wiki/Scytonemin (accessed on 25 February 2020).

84. Matsui, K.; Nazifi, E.; Hirai, Y.; Wada, N.; Matsugo, S.; Sakamoto, T. The cyanobacterial UV-absorbing pigment scytonemin displays radical-scavenging activity. J. Gen. Appl. Microbiol. 2012, 58, 137-144. [CrossRef]

85. Stevenson, C.S.; Capper, E.A.; Roshak, A.K.; Marquez, B.; Eichman, C.; Jackson, J.R.; Mattern, M.; Gerwick, W.H.; Jacobs, R.S.; Marshall, L.A. The identification and characterization of the marine natural product scytonemin as a novel antiproliferative pharmacophore. J. Pharmacol. Exp. Ther. 2002, 303, 858. [CrossRef]

86. Takamatsu, S.; Hodges, T.W.; Rajbhandari, I.; Gerwick, W.H.; Hamann, M.T.; Nagle, D.G. Marine natural products as novel antioxidant prototypes. J. Nat. Prod. 2003, 66, 605-608. [CrossRef]

87. Sinha, R.P.; Häder, D.-P. UV-protectants in cyanobacteria. Plant. Sci. 2008, 174, 278-289. [CrossRef] 
88. Rastogi, R.P.; Sonani, R.R.; Madamwar, D. Cyanobacterial sunscreen scytonemin: Role in photoprotection and biomedical research. Appl. Biochem. Biotechnol. 2015, 176, 1551-1563. [CrossRef]

89. Ekebergh, A.; Sandin, P.; Mårtensson, J. On the photostability of scytonemin, analogues thereof and their monomeric counterparts. Photochem. Photobiol. Sci. 2015, 14, 2179-2186. [CrossRef] [PubMed]

90. Ninomiya, M.; Satoh, H.; Yamaguchi, Y.; Takenaka, H.; Koketsu, M. Antioxidative activity and chemical constituents of edible terrestrial alga Nostoc commune Vauch. Biosci. Biotechnol. Biochem. 2011, 75, 2175-2177. [CrossRef] [PubMed]

91. Garcia-Pichel, F.; Sherry, N.D.; Castenholz, R.W. Evidence for an ultraviolet sunscreen role of the extracellular pigment scytonemin in the terrestrial cyanobacterium Chlorogloeopsis sp. Photochem. Photobiol. 1992, 56, 17-23. [CrossRef] [PubMed]

92. Portwich, A.; Garcia-Pichel, F. Biosynthetic pathway of mycosporines (mycosporine-like amino acids) in the cyanobacterium Chlorogloeopsis sp. strain PCC 6912. Phycologia 2003, 42, 384-392. [CrossRef]

93. Rastogi, R.P.; Sinha, R.P. Biotechnological and industrial significance of cyanobacterial secondary metabolites. Biotechnol. Adv. 2009, 27, 521-539. [CrossRef]

94. Bultel-Poncé, V.; Felix-Theodose, F.; Sarthou, C.; Ponge, J.-F.; Bodo, B. New pigments from the terrestrial cyanobacterium Scytonema sp. collected on the Mitaraka inselberg, French Guyana. J. Nat. Prod. 2004, 67, 678-681. [CrossRef]

95. Grant, C.S.; Louda, J.W. Scytonemin-imine, a mahogany-colored UV/Vis sunscreen of cyanobacteria exposed to intense solar radiation. Org. Geochem. 2013, 65, 29-36. [CrossRef]

96. Rastogi, R.P.; Sonani, R.R.; Madamwar, D. The high-energy radiation protectant extracellular sheath pigment scytonemin and its reduced counterpart in the cyanobacterium Scytonema sp. R77DM. Bioresour. Technol. 2014, 171, 396-400. [CrossRef]

97. Vincent, W.F. Cold tolerance in Cyanobacteria and life in the cryosphere. In Algae and Cyanobacteria in Extreme Environments; Seckbach, J., Ed.; Springer: Berlin/Heidelberg, Germany, 2007; pp. 288-300.

98. Oren, A.; Gunde-Cimerman, N. Mycosporines and mycosporine-like amino acids: UV protectants or multipurpose secondary metabolites? FEMS Microbiol. Lett. 2007, 269, 1-10. [CrossRef]

99. Wada, N.; Sakamoto, T.; Matsugo, S. Mycosporine-like amino acids and their derivatives as natural antioxidants. Antioxidants 2015, 4, 603-646. [CrossRef]

100. Karsten, U. Defense strategies of algae and cyanobacteria against solar ultraviolet radiation. In Algal Chemical Ecology; Amsler, C., Ed.; Springer: Berlin/Heidelberg, Germany, 2008; pp. 273-296.

101. Richa, R.P.; Rastogi, S.; Kumari, K.L.; Singh, V.K.; Kannaujiya, G.; Singh, M.; Kesheri, R.P. Biotechnological potential of mycosporine-like amino acids and phycobiliproteins of cyanobacterial origin. Biotechnol. Bioinf. Bioeng. 2011, 1, 159-171.

102. Chrapusta, E.; Kaminski, A.; Duchnik, K.; Bober, B.; Adamski, M.; Bialczyk, J. Mycosporine-like amino acids: Potential health and beauty ingredients. Mar. Drugs 2017, 15, 326-356. [CrossRef] [PubMed]

103. Bhatia, S.; Garg, A.; Sharma, K.; Kumar, S.; Sharma, A.; Purohit, A.P. Mycosporine and mycosporine-like amino acids: A paramount tool against ultra violet irradiation. Phoog. Rev. 2011, 5, 138-146. [CrossRef] [PubMed]

104. Choi, Y.-H.; Yang, D.J.; Kulkarni, A.; Moh, S.H.; Kim, K.W. Mycosporine-like amino acids promote wound healing through focal adhesion kinase (FAK) and mitogen-activated protein kinases (MAP Kinases) signaling pathway in keratinocytes. Mar. Drugs 2015, 3, 7055-7066. [CrossRef] [PubMed]

105. Corinaldesi, C.; Barone, G.; Marcellini, F.; Dell'Anno, A.; Danovaro, R. Marine microbial-derived molecules and their potential use in cosmeceutical and cosmetic products. Mar. Drugs 2017, 15, 118. [CrossRef] [PubMed]

106. Pangestuti, R.; Siahaan, E.A.; Kim, S.-K. Photoprotective substances derived from marine algae. Mar. Drugs 2018, 16, 399. [CrossRef] [PubMed]

107. Böhm, G.A.; Pfleiderer, W.; Böger, P.; Scherer, S. Structure of a novel oligosaccharidemycosporine-amino acid ultraviolet A/B sunscreen pigment from the terrestrial cyanobacterium Nostoc Commune. J. Biol. Chem. 1995, 270, 9-17. [CrossRef]

108. Mueller, D.R.; Vincent, W.F.; Bonilla, S.; Laurion, S. Extremophiles, extremotrophs and broad-band pigmentation startegies in ahigh arctic ice shield system. FEMS Microbial. Ecol. 2005, 53, 73-87. [CrossRef] 
109. Stal, L.J. Cyanobacteria: Diversity and versatility, clues to life in extreme environments. In Algae and Cyanobacteria in Extreme Environments; Seckbach, J., Ed.; Springer: Berlin/Heidelberg, Germany, 2001; pp. 661-680.

110. Matsui, K.; Nazifi, E.; Kunita, S.; Wada, N.; Matsugo, S.; Sakamoto, T. Novel glycosylated mycosporinelike amino acids with radical scavenging activity from the cyanobacterium Nostoc Commune. J. Photochem. Photobiol. B 2011, 105, 81-89. [CrossRef]

111. Nazifi, E.; Wada, N.; Yamaba, M.; Asano, T.; Nishiuchi, T.; Matsugo, S.; Sakamoto, T. Glycosylated porphyra-334 and palythine-threonine from the terrestrial cyanobacterium Nostoc Commune. Mar. Drugs 2013, 11, 3124-3154. [CrossRef]

112. Nazifi, E.; Wada, N.; Asano, T.; Nishiuchi, T.; Iwamuro, Y.; Chinaka, S.; Matsugo, S.; Sakamoto, T. Characterization of the chemical diversity of glycosylated mycosporine-like amino acids in the terrestrial cyanobacterium Nostoc Commune. J. Photochem. Photobiol. B 2015, 142, 154-168. [CrossRef] [PubMed]

113. Oren, A.; Seckbach, J. Oxygenic photosynthetic organisms in extreme environments. Nova Hedwigia 2001, 123, 13-31.

114. Rastogi, R.P.; Sonani, R.R.; Madamwar, D.; Incharoensakdi, A. Characterization and antioxidant functions of mycosporine-like amino acids in the cyanobacterium Nostoc sp. R76DM. Algal Res. 2016, 16, 110-118. [CrossRef]

115. Gao, Q.; Garcia-Pichel, F. An ATP-grasp ligase involved in the last biosynthetic step of the iminomycosporine shinorine in Nostoc punctiforme ATCC 29133. J. Bacteriol. 2011, 193, 5923-5928. [CrossRef] [PubMed]

116. Balskus, E.P.; Walsh, C.T. The genetic and molecular basis for sunscreen biosynthesis in cyanobacteria. Science 2010, 329, 1653-1656. [CrossRef] [PubMed]

117. Klisch, M.; Häder, D.P. Mycosporine-like amino acids and marine toxins-The common and the different. Mar. Drugs 2008, 6, 147-163. [CrossRef] [PubMed]

118. Singh, S.P.; Hader, D.P.; Sinha, R.P. Cyanobacteria and ultraviolet radiation (UVR) stress: Mitigation strategies. Age Res. Rev. 2010, 9, 79-90. [CrossRef]

119. Bowker, M.A.; Reed, S.C.; Belnap, J.; Phillips, S.L. Temporal variation in community composition, pigmentation, and Fv/Fm of desert cyanobacterial soil crusts. Microbial. Ecol. 2002, 43, 13-25. [CrossRef]

120. Quesada, A.; Vincent, W.F.; Lean, D.R.S. Community and pigment structure of Arctic cyanobacterial assemblages; the occurrence and distribution of UV-absorbing compounds. FEMS Microbiol. Ecol. 1999, 28, 315-323. [CrossRef]

121. Quesada, A.; Sánchez-Contreras, M.; Fernándes-Valiente, E. Tolerance of Antarctic cyanobacterial microbial mats to natural UV radiation. Nova Hedwigia 2001, 123, 275-290.

122. Xiong, F.; Kopecky, J.; Nedbal, L. The occurrence of UV-B absorbing mycosporine-like amino acids in freshwater and terrestrial microalgae (Chlorophyta). Aquat. Bot. 1999, 63, 37-49. [CrossRef]

123. Reisser, W.E.R.N.E.R.; Houben, P.E.G.G.Y. Different strategies of aeroterrestrial algae in reacting to increased levels of UV-B and ozone. Nova Hedwigia 2001, 123, 291-296.

124. Karsten, U.; Friedl, T.; Schumann, R.; Hoyer, K.; Lembcke, S. Mycosporin-like amino acids and phylogenies in green algae: Prasiola and its relatives from the Trebouxiophyceae (Chlorophyta). J. Phycol. 2005, 41, 557-566. [CrossRef]

125. Karsten, U.; Lembcke, S.; Schumann, R. The effects of ultraviolet radiation on photosynthetic performance, growth and sunscreen compounds in aeroterrestrial bil biofilm algae isolated from building facades. Planta 2007, 225, 991-1000. [CrossRef] [PubMed]

126. Karsten, U.; Holzinger, A. Green algae in alpine biological soil crust communities: Acclimation strategies against ultraviolet radiation and dehydration. Biodivers. Conserv. 2014, 23, 1845-1858. [CrossRef] [PubMed]

127. Kitzing, C.; Proschold, T.; Karsten, U. UV-induced effects on growth, photosynthetic performance and sunscreen contents in different populations of the green alga Klebsormidium fluitans (Streptophyta) from alpine soil crusts. Microb. Ecol. 2014, 67, 327-340. [CrossRef] [PubMed]

128. Kitzing, C.; Karsten, U. Effects of UV radiation on optimum quantum yield and sunscreen contents in members of the genera Interfilum, Klebsormidium, Hormidiella and Entransia (Klebsormidiophyceae, Streptophyta). Eur. J. Phycol. 2015, 50, 279-287. [CrossRef]

129. Hartmann, A.; Holzinger, A.; Ganzera, M.; Karsten, U. Prasiolin, a new UV-sunscreen compound in the terrestrial green macroalga Prasiola calophylla (Carmichael ex Greville) Kützing (Trebouxiophyceae, Chlorophyta). Planta 2016, 243, 161-169. [CrossRef] 
130. Rindi, F.; Guiry, M.D. Composition and spatial variability of terrestrial algal assemblages occurring at the al variability of terrestrial algal assemblages occurring at the bases of urban walls in Europe. Phycologia 2004, 43, 225-235. [CrossRef]

131. Llewellyn, C.A.; Airs, R.L. Distribution and abundance of MAAs in 33 species of microalgae across 13 classes. Mar. Drugs 2010, 8, 1273-1291. [CrossRef]

132. White, D.A.; Polimene, L.; Llewellyn, C.A. Effects of ultraviolet-A radiation and nutrient availability on the cellular composition of photoprotective compounds in Glenodinium foliaceum (Dinophyceae). J. Phycol. 2011, 47, 1078-1088. [CrossRef] [PubMed]

133. Siezen, R.J. Microbial sunscreens. Microb. Biotechnol. 2011, 4, 1-7. [CrossRef] [PubMed]

134. Karsten, U.; Garcia-Pichel, F. Carotenoids and mycosporine-like amino acid compounds in members of the genus Microcoleus (Cyanobacteria)—A chemosystematic study. Syst. Appl. Microbiol. 1996, 19, 285-294. [CrossRef]

135. Karsten, U.; Maier, J.; Garcia-Pichel, F. Seasonality in UV-absorbing compounds of cyanobacterial mat communities from an intertidal mangrove flat. Aquat. Microb. Ecol. 1998, 16, 37-44. [CrossRef]

136. Sinha, P.; Muralidharan, S.; Sengupta, S.; Veerappapillai, S. A Brief Review on Antifreeze Proteins: Structure, Function and Applications. Res. J. Pharm. Biol. Chem. Sci. 2016, 7, 914-919.

137. Apone, F.; Barbulova, A.; Colucci, M.G. Plant and microalgae derived peptides are advantageously employed as bioactive compounds in cosmetics. Front. Plant. Sci. 2019, 10, 756. [CrossRef]

138. Hamed, I. The evolution and versatility of microalgal biotechnology: A review. Compr. Rev. Food Sci. Food Saf. 2016, 15, 1104-1123. [CrossRef]

139. Mackenzie, G.; Boa1, A.N.; Diego-Taboada, A.; Atkin, S.L.; Sathyapalan, T. Sporopollenin, the least known yet toughest natural biopolymer. Front. Mater. 2015, 2, 66. [CrossRef]

140. Atkinson, A.W.; Gunning, B.E.S.; John, P.C.L. Sporopollenin in the cell wall of Chlorella and other algae: Ultrastructure, chemistry, and incorporation of 14C-acetate, studied in synchronous cultures. Planta 1972, 107, 1-32. [CrossRef]

141. Priyadarshani, I.; Biswajit, R. Commercial and industrial applications of micro algae-A review. J. Algal Biomass Utln. 2012, 3, 89-100.

142. Xiong, F.; Komenda, J.; Kopecky, J.; Nedbal, L. Strategies of ultraviolet-B protection in microscopic algae. Physiol. Plant. 1997, 100, 378-388. [CrossRef]

143. Arslan, M.; Temoçin, Z.; Yiğitoğlu, M. Removal of cadmium (II) from aqueous solutions using sporopollenin. Fresen. Environ. Bull. 2004, 13, 616-619.

144. Whitelam, G.C.; Codd, G.A. Damaging effects of light on microorganisms. In Microbes in Extreme Environments; Herbert, R.A., Codd, G.A., Eds.; Academic Press: London, UK, 1986; pp. 129-169.

145. Spijkerman, E.; Wacker, A.; Weithoff, G.; Leya, T. Elemental and fatty acid composition of snow algae in Arctic habitats. Front. Microbiol. 2012, 3, 380. [CrossRef] [PubMed]

146. Kim, S.K.; Ravichandran, Y.D.; Khan, S.B.; Kim, Y.T. Prospective of the cosmeceuticals derived from marine organisms. Biotechnol. Bioprocess. Eng. 2008, 13, 511-523. [CrossRef]

147. Cohen, Z. Chemicals from Microalgae; Taylor \& Francis: London, UK, 1999.

148. Montero-Lobato, Z.; Vázgues, M.; Navarro, F.; Fuentes, F.L.; Bermejo, E.; Garbayo, I.; Vílchez, C.; Cuaresma, M. Chemically-Induced Production of Anti-Inflammatory Molecules in Microalgae. Mar. Drugs 2018, 16, 478. [CrossRef]

149. de Jesus Raposo, M.F.; de Morais, R.M.S.C.; de Morais, A.M.M.B. Health applications of bioactive compounds from marine microalgae. Life Sci. 2013, 93, 479-486. [CrossRef]

150. Vítová, M.; Goecke, F.; Sigler, K.; Řezanka, T. Lipidomic analysis of the extremophilic red alga Galdieria sulphuraria in response to changes in pH. Algal Res. 2016, 13, 218-226. [CrossRef]

151. Tolomio, C.; Berrini, C.C.; de Apolonia, F.; Galziona, L.; Masiero, L.; Moro, I.; Moschin, E. Diatoms in the thermal mud of Abano Terme, Italy (Maturation period). Algol. Stud. 2002, 105, 11-27. [CrossRef]

152. Arad, S.M.; Yaron, A. Natural pigments from red microalgae for use in foods and cosmetics. Trends Food Sci. Technol. 1992, 3, 92-97. [CrossRef]

153. Borowitzka, M.A. High-value products from microalgae-their development and commercialisation. J. Appl. Phycol. 2013, 25, 743-756. [CrossRef]

154. Zanella, L.; Pertile, P.; Massironi, M.; Massironi, M.; Caviola, E. Extracts of Microalgae and Their Application. U.S. Patent 9,974,819, 22 May 2018. 
155. El Gamal, A.A. Biological importance of marine algae. Saudi Pharm. J. 2010, 18, 1-25. [CrossRef] [PubMed]

156. Mata, T.M.; Martins, A.A.; Caetano, N.S. Microalgae for biodiesel production and other applications: A review. Renew. Sust. Energ. Rev. 2010, 14, 217-232. [CrossRef]

157. Sebök, S.; Herppich, W.B.; Hanelt, D. Development of an innovative ring-shaped cultivation system for a land-based cultivation of marine macroalgae. Aquac. Eng. 2017, 77, 33-41. [CrossRef]

158. Carvalho, C.M.; Matsudo, M.C.; Bezerra, R.P.; Camargo, L.S.F.; Sato, S. Microalgae Bioreactors. In Algal Biorefineries; Bajpai, R.K., Prokop, A., Zappi, M.E., Eds.; Springer: Berlin/Heidelberg, Germany, 2014; Volume 1, pp. 83-126.

159. Dionisio-Sese, M.L. Aquatic microalgae as potential sources of UV-screening compounds. Philipp. J. Sci. 2010, 139, 5-16.

160. Einarsson, S.; Brynjolfsdottir, A.; Krutmann, J. Pharmaceutical and Cosmetic Use of Extracts from Algae Obtainable from Saline Hot Water Sources. U.S. Patent 8,795,679, 5 August 2014.

161. O'Connor, C.; Skill, S.C.; Llewellyn, C.A. WO2011158041-Topical Composition. Available online: https://patentscope.wipo.int/search/en/detail.jsf?docId=WO2011158041\&recNum=213\&docAn= GB2011051138\&queryString=ALL:(algae\%2520production)\&maxRec=13680 (accessed on 28 February 2020).

162. Alguronic Acid. Available online: https://en.wikipedia.org/wiki/Alguronic_acid (accessed on 26 February 2020).

163. Bedoux, G.; Hardouin, K.; Burlot, A.S.; Bourgougnon, N. Bioactive components from seaweeds: Cosmetic applications and future development. Adv. Bot. Res. 2014, 71, 345-378. [CrossRef]

164. Callaghan, T.V.; Björn, L.O.; Chernov, Y.; Chapin, T.; Christensen, T.R.; Huntley, B.; Ims, R.A.; Johansson, M.; Jolly, D.; Jonasson, S.; et al. Biodiversity, distributions and adaptations of Arctic species in the context of environmental change. Ambio 2004, 33, 404-417. [CrossRef]

165. Häubner, N.; Schumann, R.; Karsten, U. Aeroterrestrial algae growing in biofilms on facades: Response to temperature and water stress. Microb. Ecol. 2006, 51, 285-293. [CrossRef]

166. Karsten, U.; Schumann, R.; Mostaert, A.S. Aeroterrestrial algae growing on man-made surfaces: What are the secrets of their ecological success? In Algae and Cyanobacteria in Extreme Environments; Seckbach, J., Ed.; Springer: Berlin/Heidelberg, Germany, 2007; pp. 583-597.

167. Mager, D.M.; Thomas, A.D. Extracellular polysaccharides from cyanobacterial soil crusts: A review of their role in dryland soil processes. J. Arid Environ. 2011, 75, 91-97. [CrossRef]

168. Leelapornpisid, P.; Mungmai, L.; Sirithunyalug, B.; Jiranusornkul, S.; Peerapornpisal, Y. A novel moisturizer extracted from freshwater macroalga [Rhizoclonium hieroglyphicum (C.Agardh) Kützing] for skin care cosmetic. Chiang Mai J. Sci. 2014, 41, 1195-1207.

169. Vaibhav, V.; Sahasrabuddhe, S. 'BLUE' is the new 'GREEN' for Cosmetic Industry. Int. J. Res. Trends Innov. 2018, 3, 134-144.

170. Gloauguen, V.; Garbacki, N.; Petit, D.; Morvan, H.; Hoffmann, L. Bioactive capsular polysaccharide from the thermophilic Mastigocladus laminosus (Cyanophyceae/Cyanobacteria): Demonstration of anti-inflammatory properties. Algol. Stud. 2003, 108, 63-73. [CrossRef]

171. Rinaudo, M. Chitin and chitosan: Properties and applications. Prog. Polym. Sci. 2006, 31, 603-632. [CrossRef]

172. Younes, I.; Rinaudo, M. Chitin and chitosan preparation from marine sources. Structure, properties and applications. Mar. Drugs 2015, 13, 1133-1174. [CrossRef] [PubMed]

173. Brigham, C.J. Chitin and chitosan: Sustainable, medically relevant biomaterials. Int. J. Biotechnol. Wellness Ind. 2017, 6, 41-47. [CrossRef]

174. Cheba, B.A. Chitin and chitosan: Marine biopolymers with unique properties and versatile applications. Glob. J. Biotechnol. Biochem. 2011, 6, 149-153.

175. Bonté, F. Skin moisturization mechanisms: New data. In Annales Pharmaceutiques Francaises; Elsevier: Amsterdam, The Netherlands, 2011; pp. 135-141. [CrossRef]

176. Oren, A. Diversity of organic osmotic compounds and osmotic adaptation in cyanobacteria and algae. In Algae and Cyanobacteria in Extreme Environments; Seckbach, J., Ed.; Springer: Berlin/Heidelberg, Germany, 2007; pp. 641-655.

177. Good, B.H.; Chapman, R.L. The ultrastructure of Phycopeltis (Chroolepidaceae: Chlorophyta). 1. Sporopollenin in the cell walls. Am. J. Bot. 1978, 65, 27-33. [CrossRef] 
178. Sayo, T.; Sugiyama, Y.; Inoue, S. Lutein, a nonprovitamin A, activates the retinoic acid receptor to induce HAS3-dependent hyaluronan synthesis in keratinocytes. Biosci. Biotechnol. Biochem. 2013, 6, 1282-1286. [CrossRef]

179. Palombo, P.; Fabrizi, G.; Ruocco, V.; Ruocco, E.; Fluhr, J.; Roberts, R.; Morganti, P. Beneficial long-term effects of combined oral/topical antioxidant treatment with the carotenoids lutein and zeaxanthin on human skin: A double-blind, placebo-controlled study. Skin Pharmacol. Physiol. 2007, 20, 199-210. [CrossRef]

180. Patel, A.; Matsakas, L.; Rova, U.; Christakopoulos, P. Heterotrophic cultivation of Auxenochlorella protothecoides using forest biomass as a feedstock for sustainable biodiesel production. Biotechnol. Biofuels 2018, 11, 169. [CrossRef]

181. Ganuza, E.; Yang, S.; Mezquita, M.; Giraldo-Silva, A.A.; Andersen, R.A. Genomics, biology and phylogeny Aurantiochytrium acetophilum sp. nov. (Thraustrochytriaceae), including first evidence of sexual reproduction. Protist 2019, 170, 209-232. [CrossRef]

182. Andersen, R.A.; Ganuza, E. Nomenclatural errors in the Thraustochytridales (Heterokonta/Staminipila), especially with regard to the type species of Schizochytrium. Notulae Algarum 2018, 64, 1-8.

183. Chodchoey, K.; Verduyn, C. Growth, fatty acid profile in major lipid classes and lipid fluidity of Aurantiochytrium mangrovei SK-02 as a function of growth temperature. Braz. J. Microbiol. 2012, 43, 187-200. [CrossRef]

184. Patel, A.; Rova, U.; Christakopoulos, P.; Matsakas, L. Simultaneous production of DHA and squalene from Aurantiochytrium sp. grown on forest biomass hydrolysates. Biotechnol. Biofuels 2019, 12, 255. [CrossRef] [PubMed]

185. Ratledge, C. Microbial oils: An introductory overview ofcurrent status and future prospects. OCL-Oilseeds Fats Crops Lipids 2013, 20, D602. [CrossRef]

186. DSM. Evonik Predict Retailers Will Drive Changeto Novel Omega-3 Oils in Salmon Industry. Undercurrentnews. Available online: https://www.undercurrentnews.com/2018/10/30/dsm-evonik-predictretailers-will-drive-change-to-novel-omega-3-oils-in-salmon-industry/ (accessed on 26 February 2020).

187. Kim, S.-K. Marine cosmeceuticals. J. Cosmet. Dermatol. 2014, 13, 56-67. [CrossRef]

188. Cha, S.H.; Ko, S.C.; Kim, D.; Jeon, Y.J. Screening of marine algae for potential tyrosinase inhibitor: Those inhibitors reduced tyrosinase activity and melanin synthesis in zebrafish. J. Dermatol. 2011, 38, 354-363. [CrossRef]

189. Babitha, S.; Kim, E.-K. Effect of marine cosmeceuticals on the pigmentation of skin. In Marine Cosmeceuticals: Trends and Prospects; Kim, S.-K., Ed.; CRC Press: New York, NY, USA, 2011; pp. 63-66.

190. Hagino, H.; Saito, M. Use of Algal Proteins in Cosmetics. U.S. Patent 10/739,085, 8 July 2004.

191. Ambati, R.R.; Phang, S.M.; Ravi, S.; Aswathanarayana, R.G. Astaxanthin: Sources, extraction, stability, biological activities and its commercial applications-A review. Mar. Drugs 2014, 12, 128-152. [CrossRef]

192. Tominaga, K.; Hongo, N.; Karato, M.; Yamashita, E. Cosmetic benefits of astaxanthin on humans subjects. Acta Biochim. Pol. 2012, 59, 43-47. [CrossRef]

193. Sathasivam, R.; Ki, J.-S. A review of the biological activities of microalgal carotenoids and their potential use in healthcare and cosmetic industries. Mar. Drugs 2018, 16, 26. [CrossRef]

194. Shimoda, H.; Tanaka, J.; Shan, S.J.; Maoka, T. Anti-pigmentary activity of fucoxanthin and its influence on skin mRNA expression of melanogenic molecules. J. Pharm. Pharmacol. 2010, 62, 1137-1145. [CrossRef]

195. Thomas, N.V.; Kim, S.K. Beneficial effects of marine algal compounds in cosmeceuticals. Mar. Drugs 2013, 11, 146-164. [CrossRef] [PubMed]

196. Wijesinghe, W.A.J.P.; Jeon, Y.J. Biological activities and potential cosmeceutical applications of bioactive components from brown seaweeds: A review. Phytochem. Rev. 2011, 10, 431-443. [CrossRef]

197. Koller, M.; Muhr, A.; Braunegg, G. Microalgae as versatile cellular factories for valued products. Algal Res. 2014, 6, 52-63. [CrossRef]

198. Manirafasha, E.; Ndikubwimana, T.; Zen, X.; Lu, Y.; Jing, K. Phycobiliprotein: Potential microalgae derived pharmaceutical and biological reagent. Biochem. Eng. J. 2016, 109, 282-296. [CrossRef]

199. Bermejo, R.; Gabriel Acién, F.; Ibáñez, M.J.; Fernéndez, J.M.; Molina, E.; Alvarez-Pez, J.M. Preparative purification of B-phycoerythrin from the microalga Porphyridium cruentum by expanded-bed adsorption chromatography. J. Chromatogr. B 2003, 790, 317-325. [CrossRef]

200. Chandra, R.; Parra, R.; Iqbal, H.M.N. Phycobiliproteins: A novel green tool from marine origen blue-green algae and red algae. Protein Pept. Lett. 2017, 24, 118-125. [CrossRef] 
201. Pinto, G. Cyanidiophyceae: Looking back-looking forward. In Algae and Cyanobacteria in Extreme Environments; Seckbach, J., Ed.; Springer: Berlin/Heidelberg, Germany, 2001; pp. 389-397.

202. Guiry, M.D.; Guiry, G.M. AlgaeBase. World-Wide Electronic Publication. National University of Ireland: Galway, Ireland, 2020. Available online: https://www.algaebase.org (accessed on 26 February 2020).

203. Dyes and Colorants From Algae. Available online: http://www.seacolors.eu/images/dyes_and_colourants_ from_algae.pdf (accessed on 26 February 2020).

204. Jain, R.; Raghukumar, S.; Tharanathan, R.; Bhosle, N.B. Extracellular polysaccharide production by thraustochytrid protists. Mar. Biotechnol. 2005, 7, 184-192. [CrossRef]

205. Raposo, M.; Morais, R.; Morais, A. Bioactivity and applications of sulphated polysaccharides from marine microalgae. Mar. Drugs 2013, 11, 233-252. [CrossRef]

206. Kadam, S.U.; Tiwari, B.K.; O'Donnell, C.P. Application of novel extraction technologies for bioactives from marine algae. J. Agric. Food Chem. 2013, 61, 4667-4675. [CrossRef]

207. Ibanez, E.; Herrero, M.; Mendiola, J.A.; Castro-Puyana, M. Extraction and characterization of bioactive compounds with health benefits from marine resources: Macro and micro algae, cyanobacteria, and invertebrates. In Marine Bioactive Compounds: Sources, Characterization and Applications; Hayes, M., Ed.; Springer: Berlin/Heidelberg, Germany, 2012; pp. 55-98.

208. Dutta, P.K.; Dutta, J.; Tripathi, V.S. Chitin and chitosan: Chemistry, properties and applications. J. Sci. Ind. Res. 2004, 63, 20-31.

209. Sionkowska, A.; Kaczmarek, B.; Michalska, M.; Lewandowska, K.; Grabska, S. Preparation and characterization of collagen/chitosan/hyaluronic acid thin films for application in hair care cosmetics. Pure Appl. Chem. 2017, 89, 1829-1839. [CrossRef]

210. Hosikian, A.; Lim, S.; Halim, R.; Danquah, M.K. Chlorophyll extraction from microalgae: A review on the process engineering aspects. Int. J. Chem. Eng. 2010, 2010. [CrossRef]

211. Bentley, F.K.; García-Cerdán, J.G.; Chen, H.C.; Melis, A. Paradigm of monoterpene ( $\beta$-phellandrene) hydrocarbons production via photosynthesis in cyanobacteria. Bioenerg. Res. 2013, 6, 917-929. [CrossRef]

212. Meriluoto, J.; Spoof, L.; Codd, G.A. (Eds.) Handbook of Cyanobacterial Monitoring and Cyanotoxin Analysis; John Wiley \& Sons, Ltd.: Chichester, UK, 2017.

213. Evangelista, V.; Barsanti, L.; Frassanito, A.M.; Passarelli, V.; Gualtieri, P. Algal Toxins: Nature, Occurrence, Effect and Detection; Springer: Dordrecht, The Netherlands, 2008; pp. 211-220.

(C) 2020 by the authors. Licensee MDPI, Basel, Switzerland. This article is an open access article distributed under the terms and conditions of the Creative Commons Attribution (CC BY) license (http://creativecommons.org/licenses/by/4.0/). 